Acta vet. scand. $1960,1,294-299$.

From the State Veterinary Institute for Virus Research, Lindholm per Kalvehave, Denmark.

\title{
COMPLEMENT FIXATION REACTION OF FOOT AND MOUTH DISEASE. I.
} THE IMPORTANCE OF THE AMOUNT OF ANTIGEN

By

Knud Schjerning-Thiesen.

The applied complement fixation technique corresponds in principle to the one indicated by Mayer et al. (1). 50 complement units are employed, and the antigens are obtained from vesical epithelium from $50-60$ cows.

Through preliminary investigations, which are not to be reported here, are first determined the approximate amounts of antigen and immune serum for a suitable fixation (i.e. corresponding to a consumption of $10-40$ complement units).

On the basis of these investigations are then chosen the most expedient amounts with which the ultimate results are obtained (fig. 1 and 2).

Curve $I$ in fig. 1 and 2 show the unspecific complement-fixing strength of the antigen (anticomplementary effect) ${ }^{1}$ ). The curve is gradually increasing together with the increase of the amount of antigen, but yet in such a way that the increase is relatively greatest in the beginning (which is most clearly seen with the O-antigen). In its further course the curve shows a markedly linear tendency, which is fortunate for the graphical representation of the antigen curve.

Curve III in fig. 2, which shows the unspecific + specific complement-fixing strength, has a very characteristic course in relation to the antigen curve (curve $I$ ), in that the distance between the two curves is considerably increased (corresponding

1) The unspecific complement-fixing strength of the immunizing serum is in the applied amounts 0 . 


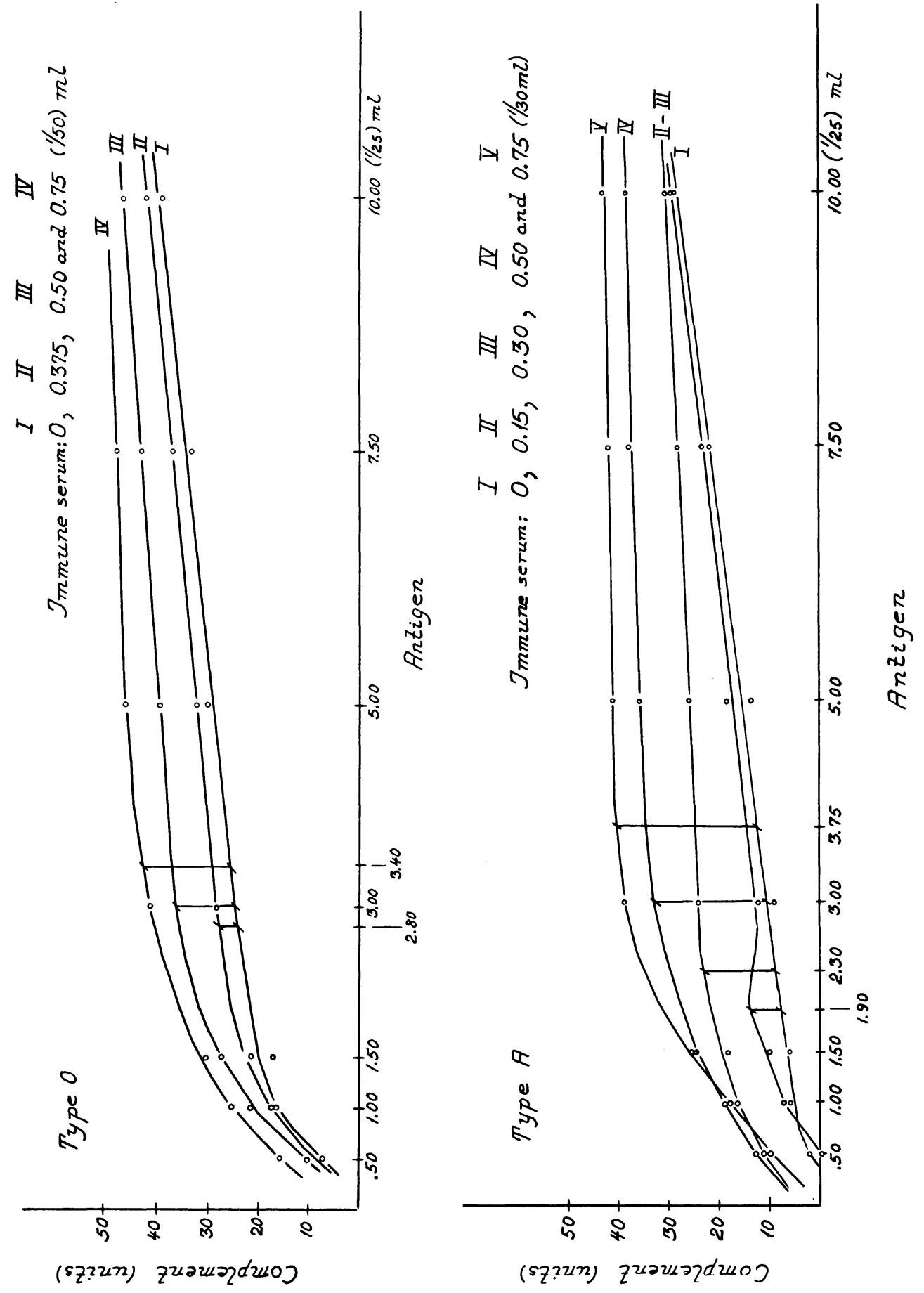

F i g. 1 and 2: Complement units fixed by constant amounts of immune serum with different amounts of antigen. The amounts of antigen necessary for the maximum fixation, called the optimum amounts, are determined. 
to $9-14$ units) where from 0.50 to $2.10 \mathrm{ml}$ of antigen is used, whereas after this the distance is again decreased. An analagous phenomenon manifests itself in the other curves of immune serum + antigen.

The increasing distance between the curves in the initial stage shows that a moderate rise of the amount of antigen is accompanied by an increase of the specific complement-fixing strength. The decreasing distance with the continuous rise of the amount of antigen, however, shows that the specific complement-fixing strength is diminished, or quite disappears, when the amount of antigen is increased considerably. The author has made the same characteristic observations with ten different antigens.

The described phenomenon is often designated as "the excess phenomenon". Another expression, which is also frequently seen in the scientific literature, viz. "the prozone phenomenon", is only applicable when the investigations have been carried out with dilution series of the antigen. The less fixation is then seen in the first tubes, i.e. those with the great concentrations.

In the present work the latter expression cannot be used on occount of the applied procedure.

From the scientific literature is seen that the antigen excess phenomenon has been observed with several bacterial antigens, viz. syphilis (Wadsworth et al. (5 and 6)), gonorrhoea (Wadsworth (4)), and also pneumonia, caused by cocci (Rice (3), Osler et al. (2), and Wallace et al. (7)). In tuberculosis, however, it has proved possible to work with an excess without the phenomenon being seen (Wadsworth et al. (5 and 6 )).

A strong fixation in general is not at all a token of a great specific fixation, as is clearly seen by the right half of curve III (fig. 2). Not until by correction for the unspecific fixation, however, is the correct circumstance realized.

Consequently the amount of antigen necessary for the maximum fixation, called the optimum amount, must in each separate case (i.e. in the case of each serum amount) be determined for the sake of the accuracy. The use of relatively big amounts of antigen, i.e. of so-called empirical antigen excesses, which is extensively employed, may of course on account of the less specific fixation, which is a consequence of the increasing amounts of antigen, become positively wrong. However, as the maximum distance between the curves is represented by a broad area, the 

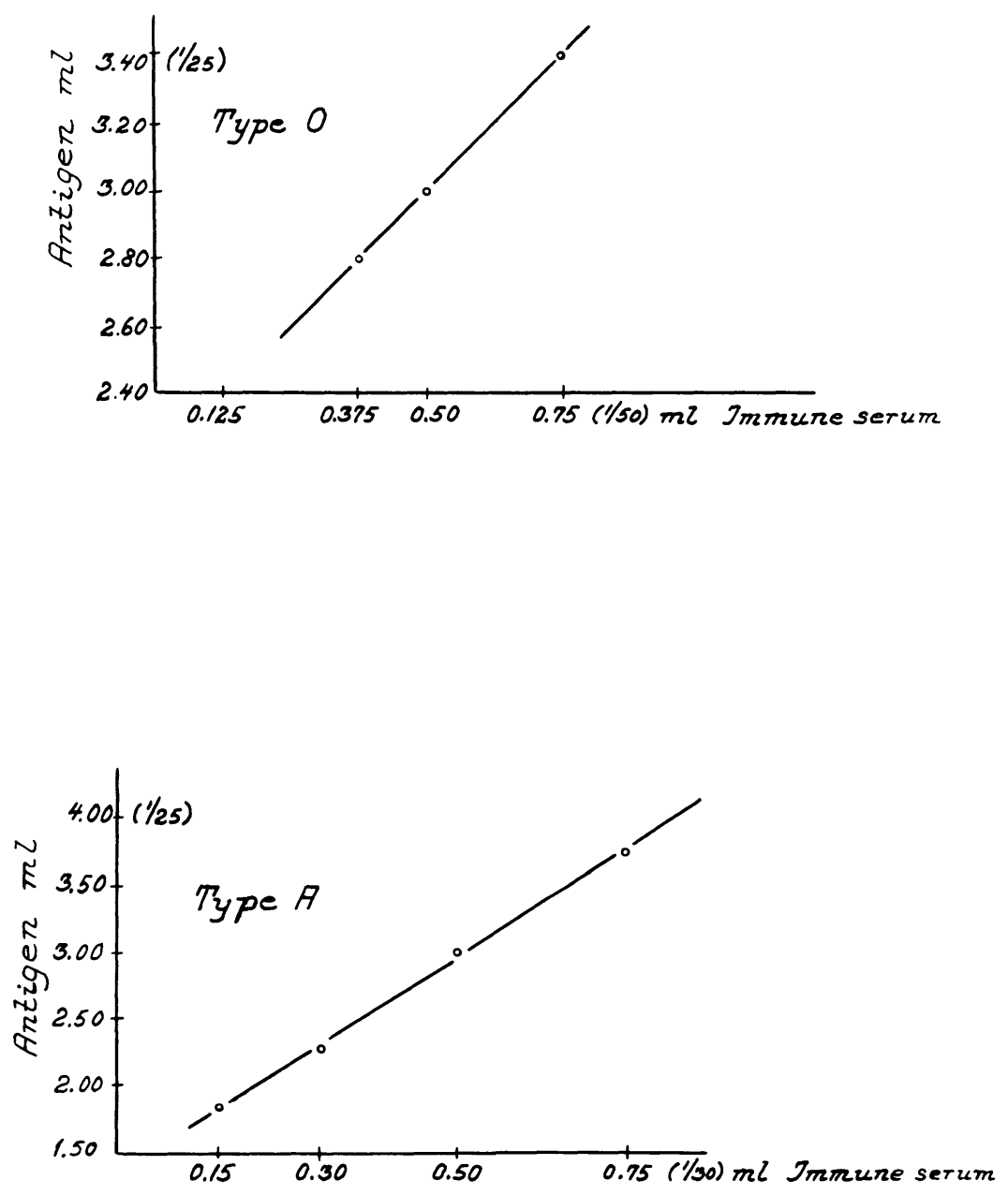

F i g. 3 and 4: Different chosen amounts of immune serum and corresponding optimum amounts of antigen. The curves show a markedly linear course. 
selection of the optimum antigen amount need not be made under exercise of strict accuracy.

Graphically the chosen amounts of immune serum and the corresponding optimum amounts of antigen show a linear tendency, as will appear from fig. 3 and 4 . It is also seen that corresponding to a bigger amount of immune serum is a bigger optimum amount of antigen. There is no direct proportionality between corresponding amounts of immune serum and antigen, as the curves must have then passed through zero of the co-ordinate system. The curves are of a certain practical value, as it is possible by means of these to select the optimum amounts of antigen corresponding to other amounts of immune serum.

\section{REFERENCES}

1. Mayer, M. M., A. G. Osler, O. G. Bier \& M. Heidelberger: Jour. Immunol. 1948, 59, 195.

2. Osler, A. G., M. M. Mayer \& M. Heidelberger: Jour. Immunol. 1948, $60,205$.

3. Rice, C. E.: Jour. Immunol. 1942, 43, 129.

4. Wadsworth, A. B.: Standard Methods. 1947.

5. Wadsworth, A., F. Maltaner \& E. Maltaner: Jour. Immunol. 1938, $35,105$.

6. Wadsworth, A., F. Maltaner \& E. Maltaner: Jour. Immunol. 1938, $35,217$.

7. Wallace, A. L., A. G. Osler \& M. M. Mayer: Jour. Immunol 1950, 65,661 .

\section{SUMMARY}

Investigations into the importance of the amount of antigen in the complement fixation reaction of foot and mouth disease show that with the use of a constant amount of immune serum, a maximum specific fixation is only seen with an optimum amount of antigen. Thus with foot and mouth disease virus as with various other antigens, a so-called antigen excess phenomenon can be proved. So in exact determinations, e.g. type differentiations, the amount of antigen must be determined in each separate case. The investigations also show that a linear relation exists between amounts of immune serum and the corresponding optimum amounts of antigen, when these qualities are entered in a co-ordinate system.

\section{ZUSAMMENFASSUNG}

Die Komplementbindungsreaktion bei Maul- und Klauenseuche. I. Die Bedeutung der Antigenmenge.

Untersuchungen über die Bedeutung der Antigenmenge in der Komplementbindungsreaktion bei Maul- und Klauenseuche zeigen, dass 
beim Gebrauch einer konstanten Immunserummenge nur mit einer optimalen Antigenquantität eine maximale spezifische Bindung erzielt wird. Mit Maul- und Klauenseuchevirus lässt sich ebenso wie mit verschiedenen anderen Antigen ein sogenanntes Antigenüberschussphänomen wahrnehmen. Bei genauen Bestimmungen, z. B. Typendifferenzierungen, soll deshalb die Antigenmenge in jedem einzelnen Fall festgelegt werden. Die Untersuchungen zeigen ebenfalls, dass sich zwischen den Immunserummengen und den hiermit korrespondierenden optimalen Antigenquantitäten eine lineare Relation findet, wenn diese Grössen in ein Koordinatensystem eingetragen werden.

\section{SAMMENDRAG}

Komplementbindingsreaktionen ved mund-og klovesyge. I. Antigenmængdens betydning.

Undersøgelser over antigenmængdens betydning i komplementbindingsreaktionen ved mund- og klovesyge viser, at der under anvendelse af en konstant immunserummængde kun ses en maximal specifik binding med en optimal antigenmængde. Med mund- og klovesygevirus kan der således ligesom med forskellige andre antigener påvises et såkaldt antigenoverskudsfænomen. Ved eksakte bestemmelser, f. eks. typedifferentieringer, må antigenmængden derfor fastlægges i hvert enkelt tilfælde. Undersøgelserne viser ligeledes, at der mellem immunserummængder og hermed korresponderende optimale antigenmængder findes en lineær relation, når disse størrelser indføres $i$ et koordinatsystem.

(Received May 11. 1960). 